\title{
A Clínica Ampliada e a Reabilitação: Ressignificando a Intervenção
}

\author{
Petrokas, Rejane Cristina; Morais, Camila Aparecida de; Pinheiro, Andressa \\ Moreira; Sousa, Mariza Regina Tavares de; Nunes, Letícia Ferro Carapeto; \\ Ragassi, Renata \\ Oss Santa Marcelina — rejokas@yahoo.com.br
}

e a Humanização em Saúde na prática desenvolvida no contexto da reabilitação, tendo em vista a linha de cuidado e os projetos terapêuticos singulares de usuários na rede de serviços do território. METODOLOGIA: o estudo de atualização baseia-se na reflexão acerca dos manuais e cartilhas publicados pelo Ministério da Saúde e a organização e desenvolvimento de ações na prática cotidiano, desenvolvida de forma interdisciplinar na instituição referida. RESULTADOS e CONCLUSÕES: a humanização no atendimento passa pelo exercício do diálogo e autonomia nas relações entre os profissionais sejam esses administrativos, gestores e técnicos, pois é necessário o esforço de somar as forças de resiliência, de superação de cada sujeito para oferecer uma assistência mais potente. Assim, é possível aos profissionais explorar o potencial dos usuários atendidos, que implica no esforço pessoal de cada profissional em assumir uma atitude ética e de cuidado que sempre seja somada a novas forças, também extra-equipe, como os profissionais dos Núcleos de Apoio à Saúde da Família (NASF) e de outras instituições, tanto nas reuniões quanto nos contatos telefônicos, em vista da troca de informações e necessidade da escuta das angústias e em vista da abordagem e da resolutividade ou assistência em problemáticas muitas vezes tão complexas e multifatoriais. por exemplo, a abordagem de uma paciente com sintomas de síndrome do túnel do carpo, pode ser pensada também na capacitação para mudança de função de trabalho e a discussão acerca do projeto de vida, e evitar o raciocínio simplista de abordagem de exercícios e orientações quanto à condição física. Tal forma de atuação pretende estar embasada nas diretrizes do Sistema Único de Saúde e apoiados na Clínica Ampliada.

Petrokas, Rejane Cristina; Morais, Camila Aparecida de; Pinheiro, Andressa Moreira; Sousa, Mariza Regina Tavares de; Nunes, Letícia Ferro Carapeto; Ragassi, Renata. A Clínica Ampliada e a Reabilitação: Ressignificando a Intervenção. In: Anais do Congresso Internacional de Humanidades \& Humanização em Saúde [= Blucher Medical Proceedings, num.2, vol.1]. São Paulo: Editora Blucher, 2014. ISSN 2357-7282 DOI 10.5151/medpro-cihhs-10819 